\title{
Penerapan Media Powerpoint Untuk Meningkatkan Aktivitas Dan Hasil Belajar Pengetahuan Dasar Teknik Bangunan Pada Siswa Kelas X Program Keahlian Gambar Bangunan SMK Negeri 1 Merdeka Berastagi Tahun Ajaran 2012/2013
}

\author{
Rustam Efendi Tambunan ${ }^{1)}$ Dan Edim Sinuraya ${ }^{2)}$ \\ E-mail : edimsinuraya@yahoo.com
}

\begin{abstract}
ABSTRAK
Penelitian bertujuan ini untuk meningkatkan aktivitas dan hasil belajar Pengetahuan Dasar Teknik Bangunan (PDTB) siswa kelas X di SMK Negeri 1 Merdeka Berastagi dengan menerapkan Media Powerpoint. Subjek penelitian adalah siswa kelas X program Keahlian Teknik Gambar Bangunan SMK Negeri 1 Merdeka T.A 2012/ 2013 dengan jumlah siswa sebanyak 30 orang, metode penelitian ini bersifat deskriptif.

Sebelum penelitian dilakukan terlebih dahulu tes belajar PDTB di uji cobakan dilanjutkan uji validitas dan reabilitas. Perhitungan uji validitas butir digunakan rumus Biserial dan uji reabilitas digunakan $K-R$ 20. Butir tes dikatakan valid apabila $r_{\text {hitung }}>r_{\text {tabel }}$ pada taraf signifikan 5\%. Dengan hasil tes digunakan 15 soal dengan nilai $r_{11}=0,61$ maka reliabilitas soal adalah tinggi untuk siklus I dan 20 soal dengan nilai $r_{11}=0,74$ maka reliabilitas soal adalah tinggi untuk siklus II. Hasil penelitian siklus I aktivitas belajar siswa belum meningkat, tetapi setelah dilakukan siklus II aktivitas siswa meningkat. Dimana aktivitas siswa pada siklus I dengan kategori Tidak Baik sebanyak 10 siswa, Kurang Baik sebanyak 9 siswa, Cukup Baik sebanyak 8 siswa, Baik sebanyak 3 siswa, sedangkan pada siklus II mengalami peningkatan yaitu untuk kategori Tidak Baik, Kurang Baik tidak ada, Cukup Baik dari 9 siswa menjadi 7 siswa, Baik dari 7 siswa menjadi 21 siswa dan Sangat Baik dari nol menjadi 4 siswa. Hasil penelitian PDTB siswa siklus I nilai rata-rata hasil belajar PDTB siswa adalah 62 dengan keterangan siswa tidak kompeten 6 orang, kurang kompeten 11 orang, cukup kompeten 8 orang, kompeten 5 orang, dan yang sangat kompeten tidak ada. Pada siklus II nilai rata-rata hasil belajar PDTB siswa meningkat menjadi 81 dengan keterangan siswa yang sangat kompeten 6 orang, kompeten 17 orang, cukup kompeten 5 orang, sudah tidak ada siswa yang kurang kompeten dan tidak kompeten. Maka peningkatan hasil belajar mencapai $19 \%$.

Dari data-data hasil penelitian dapat disimpulkan bahwa aktivitas dan hasil belajar siswa meningkat dengan menerapkan media powerpoint.
\end{abstract}

Kata Kunci : Powerpoint, Aktivitas, Hasil Belajar

\section{PENDAHULUAN}

Sesuai Dengan Kurikulum Tingkat Satuan Pendidikan (KTSP) SMK (2006), SMK memiliki tujuan untuk : 1) menyiapkan peserta didik agar menjadi manusia produktif, mampu bekerja mandiri, mengisi lowongan pekerja yang ada di dunia usaha dan dunia industri sebagai tenaga kerja tingkat menengah sesuai dengan kompetisi dalam program keahlian yang di pilihnya, 2) menyiapkan peserta didik agar mampu memilih karir, ulet dan gigih dalam berkompetensi, beradaptasi di lingkungan kerja, dan mengembangkan sikap profesionaldalam bidang keahlian yang di minatnya, 3) membekali peserta didik dengan ilmu pengetahuan, teknologi dan seni, agar mampu mengembangkan diri di kemudian hari baik secara mandiri maupun melalui

Rustam Efendi Tambunan ${ }^{1)}$ dan Edim Sinuraya ${ }^{2)}$. Dosen Jurusan Pendidikan Teknik Bangunan FT Unimed 
Penerapan Media Powerpoint Untuk Meningkatkan Aktivitas Dan Hasil Belajar Pengetahuan Dasar Teknik Bangunan Pada Siswa Kelas X Program Keahlian Gambar Bangunan SMK Negeri 1 Merdeka Berastagi Tahun Ajaran 2012/2013

jenjang pendidikan yang lebih tinggi, 4) membekali peserta didik dengan kompetensikompetensi yang sesuai dengan program keahlian yang di pilihnya.

Pengajaran PDTB adalah proses pengajaran teknik dan kejuruan yang sangat penting karena PDTB dapat mengantarkan siswa kepada dasar pemahaman program produktif lainnya, seperti mata pelajaran kontruksi kayu, kontruksi beton, kontruksi baja, dan sebagainya. Kelemahan dalam memahami mata pelajaran PDTB akan berdampak negatif terhadap penguasaan program produktif lainnya.

Berdasarkan hasil wawancara peneliti dengan guru mata pelajaran PDTB di SMK N. 1 Merdeka, beliau menyatakan bahwa hasil belajar siswa kelas $\mathrm{X}$ dimana jika di lihat dari DKN (daftar kumpulan nilai) siswa, jumlah siswa yang nilainnya di atas KKM (kriteria ketuntasan minimal) dari seluruh kelas X yang berjumlah 30 orang hanya 16 orang (sekitar 53, 33\%) selainnya siswa tersebut memperoleh nilai dibawah KKM. Padahal menurut beliau telah banyak metode pembelajaran yang diterapkan dalam proses pembelajaran seperti metode diskusi sederhana, penugasan, bahkan penemuan di laboratorium untuk meningkatkan hasil belajar tapi hasilnya tetap sama saja, hasil belajar siswa rendah. Karena hal tersebut beliau memilih untuk mengajar dengan menggunakan metode konvensional saja, tanpa merepleksikan dimana kekurangan dan kelebihan dari penerapan model yang digunakan sehingga tidak berhasil meningkatkan hasil belajar siswa.

Menurut Kolb dalam Trianto (2009) proses belajar dibagi kedalam tiga tahapan. Tahapan pertama, seorang siswa hanya mampu ikut mengalami suatu kejadian. Siswa belum mempunyai kesadaran tentang hakekat kejadian tersebut. Siswa juga belum mengerti bagaimana dan mengapa suatu kejadian terjadi seperti itu. Inilah yang terjadi dalam tahap pertama belajar. Pada tahap kedua, siswa tersebut lambat laun mampu mengadakan observasi aktif terhadap kejadian itu. Serta berusaha memikirkan dan memahaminya. Pada tahapan yang ketiga, siswa mulai belajar membuat abstraksi atau teori tentang suatu hal yang pernah diamati. Menurut Clark dalam Wydiastono (2009) kreatifitas seseorang dapat dicerminkan melalui 5 macam perilaku yaitu : 1) Fluency ;2) Flexibility ;3) Originality ;4) Elaboration dan 5) Sensitivy. Dengan demikian, ditinjau dari segi pribadi, kreativitas menunjuk pada potensi atau daya kreatif yang ada pada setiap pribadi. Kreativitas merupakan hasil dari keunikan pribadi seseorang dalam interaksinya dengan lingkungan. Tapi hal tersebutlah yang tidak dapat ditemui dalam proses pembelajaran yang dilakukan oleh guru.

Untuk meningkatkan kualitas proses dan hasil belajar, para ahli pembelajaran telah menyarankan penggunaan paradigma pembelajaran untuk kegiatan belajar mengajar di kelas. Dengan adanya perubahan paradigma belajar tersebut, maka terjadi perubahan pusat (fokus) pembelajaran, dari belajar terpusat pada guru menjadi belajar berpusat pada siswa. Dengan kata lain, ketika mengajar di kelas, guru harus berupaya menciptakan kondisi lingkungan belajar yang dapat membelajarkan siswa, dapat mendorong siswa belajar, atau memberi kesempatan kepada siswa untuk berperan aktif untuk mengkontruksi konsep-konsep yang di pelajarinya. Kondisi belajar dimana siswa hanya menerima materi dari guru, mencatat dan menghafalkannya harus diubah menjadi sharing pengetahuan, mencari (inkuiri), menemukan pengetahuan secara aktif sehingga terjadi peningkatan pemahaman bukan sekedar ingatan. Untuk mencapai tujuan tersebut, guru dapat 
Penerapan Media Powerpoint Untuk Meningkatkan Aktivitas Dan Hasil Belajar Pengetahuan Dasar Teknik Bangunan Pada Siswa Kelas X Program Keahlian Gambar Bangunan SMK Negeri 1 Merdeka Berastagi Tahun Ajaran 2012/2013

menggunakan media pembelajaran yang inovatif. Salah satu upaya yang dapat dilakukan untuk menyikapi persoalan dimaksud adalah dengan penggunaan media Power Point sebagai media pembelajaran.

Berdasarkan latar belakang diatas, maka penulisan tertarik untuk melakukan penelitian dengan judul "Penerapan Media Powerpoint Untuk Meningkatkan Aktivitas dan Hasil Belajar Pengetahuan Dasar Teknik Bangunan (PDTB) Pada Siswa Kelas X Program Keahlian Teknik Gambar Bangunan SMK Negeri 1 Merdeka Tahun Ajaran 2012-2013”.

\section{A. Tujuan penelitian}

Tujuan penelitian ini merupakan hal yang hendak di capai untuk melakukan suatu kegiatan yang telah dirumuskan. Adapun tujuan diadakan penelitian ini adalah untuk mengetahui:

1. Hasil belajar PDTB siswa yang diajarkan dengan menggunakan media pengajaran Microsoft Powerpoint?

2. Untuk mengetahui peningkatan hasil belajar siswa pada materi pokok tegangan setelah diajarkan dengan menggunakan media power point?

3. Untuk mengetahui aktivitas siswa pada materi pokok tegangan dengan menggunakan media powerpoint.?

\section{B. Manfaat penelitian}

Penelitian ini diharapkan dapat memberikan manfaat sebagai berikut:

1. Bagi Kepala Sekolah, memberikan informasi dalam usaha meningkatkan mutu pembelajaran di sekolah, terutama dalam memepertimbangkan penerapan media powerpoint.

2. Bagi Guru mata pelajaran :

a. Sebagai masukan dalam menentukan media pembelajaran yang lebih tepat. b. Sebagai masukan dalam meningkatkan kualitas proses pembelajaran khususnya mata diklat pengetahuan dasar teknik bangunan.

3. Bagi Siswa, sebagai sumber informasi dan motivasi untuk lebih belajar menggunakan teknologi dalam meningkatan hasil belajar.

4. Bagi Peneliti, Sebagai bandingan informasi tentang hasil belajar pengetahuan dasar teknik bangunan yang dipengaruhi oleh penerapan media powerpoint.

\section{KERANGKA TEORITIS, KERANGKA BERPIKIR DAN PENGAJUAN HIPOTESIS}

\section{A. Kerangka Teoritis \\ 1. Hakekat Hasil Belajar Pengetahuan Dasar Teknik Bangunan (PDTB)}

Sejalan dengan itu Wina Sanjaya (2008) menyatakan bahwa tidak setiap perubahan tingkah laku adalah hasil belajar. Dapat dikatakan bahwa setiap proses belajar menghasilkan perubahan tingkah laku, namun tidak setiap perubahan perilaku merupakan hasil belajar. Perubahan perilaku yang bukan merupakan hasil belajar adalah: (a) perubahan perilaku karena pengaruh obat bukan hasil belajar, (b) perubahan perilaku karena kematangan, (c) perubahan perilaku karena suatu penyakit, (d) perubahan perilaku karena pertumbuhan jasmani.

Menurut Sudjana dalam Kunandar (2008) mengemukakan bahwa hasil belajar adalah suatu akibat dari proses belajar dengan menggunakan alat pengukuran, yaitu berupa tes yang disusun secara terencana, baik tes tertulis, tes lisan, maupun tes perbuatan. Selain itu S. Nasution dalam Kunandar (2008) menambahkan bahwa belajar adalah suatu perubahan pada individu yang belajar, tidak hanya mengenai

\section{Rustam Efendi Tambunan ${ }^{1)}$ dan Edim Sinuraya ${ }^{2)}$. Dosen Jurusan Pendidikan Teknik}


Penerapan Media Powerpoint Untuk Meningkatkan Aktivitas Dan Hasil Belajar Pengetahuan Dasar Teknik Bangunan Pada Siswa Kelas X Program Keahlian Gambar Bangunan SMK Negeri 1 Merdeka Berastagi Tahun Ajaran 2012/2013

pengetahuan tetapi juga membentuk kecakapan dan penghayatan dalam diri pribadi individu yang belajar.

Dari pendapat-pendapat tersebut di atas dapat diambil kesimpulan bahwa hasil belajar merupakan hasil dari suatu tindakan belajar mengajar. Selain itu dapat dikatakan pula bahwa dengan proses belajar akan menyebabkan perubahan pada diri sendiri terhadap suatu keadaan yang lebih baik, yang mengacu pada tingkat keberhasilan dalam belajar yang diorientasikan pada hasil belajar yang dicapai. Hasil belajar tersebut dapat diketahui setelah seseorang dalam hal ini adalah peserta didik telah mendapat pembelajaran disekolah.

Untuk melihat aktivitas siswa di dalam kelas pada saat pembelajaran berlangsung dilakukan dengan catatan pengamatan aktivitas siswa yang berisi tentang berapa banyak siswa mengajukan pertanyaan, memberikan jawaban, mengerjakan tugas dan membuat kesimpulan. Selain itu untuk melihat bagaimana pendapat siswa tentang model pembelajaran yang diterapkan di dalam kelas tersebut adalah dengan menggunakan angket yang disebarkan kepada seluruh siswa dalam kelas untuk diisi. Pada akhimya diharapkan penerapan model tersebut dapat merubah keadaan belajar siswa pada mata diklat Pengetahuan Dasar Teknik Bangunan, menjadi lebih baik dan mengacu kepada tingkat keberhasilan dalam belajar yang diorientasikan pada hasil belajar yang dicapai.

\section{Hakikat Aktivitas Belajar Siswa}

Menurut Poerwadarminta (2003:23), aktivitas adalah kegiatan. Jadi aktivitas belajar adalah kegiatan-kegiatan siswa yang menunjang keberhasilan belajar. Dalam hal kegiatan belajar, Rousseuau (dalam Sardiman 2004:96) memberikan penjelasan bahwa segala pengetahuan itu harus diperoleh dengan pengamatan sendiri, penyelidikan sendiri, dengan bekerja sendiri baik secara rohani maupun teknis. Tanpa ada aktivitas, proses belajar tidak mungkin terjadi. Lebih lanjut dikatakan, pada prinsipnya belajar adalah berbuat, tidak ada belajar jika tidak ada aktivitas. Itulah mengapa aktivitas merupakan prinsip yang sangat penting dalam interaksi belajar mengajar. Dalam aktivitas belajar ada beberapa prinsip yang berorientasi pada pandangan ilmu jiwa, yaitu pandangan ilmu jiwa lama dan modern. Menurut pandangan ilmu jiwa lama, aktivitas didominasi oleh guru sedangkan menurut pandangan ilmu jiwa modern, aktivitas didominasi oleh siswa.

Prinsip-prinsip aktivitas dalam belajar dalam hal ini akan dilihat dari sudut pandang perkembangan konsepsi jiwa menurut ilmu jiwa. Dengan melihat unsur kejiwaan seseorang subjek belajar/subjek didik, dapat diketahui bagaimana prinsip aktivitas yang terjadi dalam belajar itu. Karena dilihat dari sudut pandang ilmu jiwa, maka sudah barang tentu yang menjadi fokus perhatian adalah komponen manusiawi yang melakukan aktivitas dalam belajar mengajar, yakni siswa dan guru. Untuk melihat prinsip aktivitas belajar dari sudut pandangan ilmu jiwa ini secara garis besar dibagi menjadi dua pandangan yakni ilmu jiwa lama dan ilmu jiwa modern.

Menurut Pandangan Ilmu Jiwa Lama. Menurut Locke jiwa dapat dimisalkan dengan kertas yang tak bertulis (tabularasa), kertas itu kemudian mendapat isi dari luar. Dalam pendidikan, yang memberi dan mengatur isinya adalah guru. Karena gurulah yang harus aktif sedangkan anak didik bersifaat reseptif. Sedangkan menurut Herbart jiwa adalah keseluruhan tanggapan yang secara mekanis dikuasai oleh hukum-hukum asosiasi. Disinipun guru pulalah yang harus menyampaikan tanggapan-tanggapan itu. Jadi 
Penerapan Media Powerpoint Untuk Meningkatkan Aktivitas Dan Hasil Belajar Pengetahuan Dasar Teknik Bangunan Pada Siswa Kelas X Program Keahlian Gambar Bangunan SMK Negeri 1 Merdeka Berastagi Tahun Ajaran 2012/2013

konsepsi jiwa sebagai "kertas bersih" yang harus ditulis atau sebagai bejana yang harus diisi menyebabkan gurulah yang aktif dan dari gurulah datang segala inisiatif. Gurulah yang menentukan bahan pelajaran sedangkan murid-murid bersifat reseptif dan pasif.

\section{Hakekat Media Pembelajaran}

a. Pengertian Media Pembelajaran

Kata media berasal dari bahasa latin, medium yang secara harafiah berarti tengah, perantara atau pengantar. Gerlach dan Ely 1971 mengatakan bahwa media apabila dipahami secara garis besar adalah manusia, materi, atau kejadian yang membangun kondisi yang membuat siswa mampu memperoleh pengetahuan, keterampilan atau sikap. Secara lebih khusus pengertian media dalam proses belajar mengajar cenderung diartikan alat-alat grafis fotografis atau elektronis untuk menangkap, memproses dan menyusun kembali informasi visual atau verbal.

Sementara menurut Gagne (1970) menyatakan bahwa media adalah berbagai jenis komponen dalam lingkungan siswa yang dapat merangsangnya untuk belajar. Sementara itu Briggs (1970) berpendapat bahwa media adalah segala alat fisik yang dapat menyajikan pesan serta merangsang siswa untuk belajar. Dengan kata lain, media pembelajaran adalah segala sesuatu yang dapat menyampaikan dan menyalurkan pesan dari sumber secara terencana sehingga tercipta lingkungan belajar yang kondusif dimana penerimanya dapat melakukan proses belajar secara efisian dan efektif.

Media pembelajaran yang digunakan dalam kegiatan pembelajaran dapat mempengaruhi efektifitas pembelajaran. Pada mulanya, media pembelajaran yang digunakan sebagai alat bantu guru untuk mengajar adalah alat bantuan visual.
Pertengahan abad ke-20 usaha pemanfaatan visual dilengkapi dengan digunakannya alat audio, sehingga lahirlah alat bantu audio-visual. Sejalan dengan perkembangan ilmu pengetahuan dan teknologi (IPTEK), khususnya dalam bidang pendidikan, saat ini penggunaan alat bantu atau media pembelajaran menjadi makin luas dan interaktif, seperti adanya Komputer dan internet.

Dari beberapa pendapat di atas dapat disimpulkan bahwa media pembelajaran adalah segala sesuatu yangdapat menyalurkan pesan, dapat merangsang pikiran, perasaan, dan kemauan peserta didik sehingga dapat mendorong terciptanya proses belajar pada diri peserta didik.

b. Fungsi Media Pembelajaran

Menurut Yudhi Muhadi (2008) dalam bukunya yang berjudul Media Pembelajaran, menjabarkan beberapa fungsi dari media pemebelajaran, yakni:

1. Fungsi Media Pembelajaran Sebagai Sumber Belajar

Menjadikan proses pembelajaran menjadi menarik.

2. Fungsi Semantik

Yakni kemampuan media dalam menambah perbendaharaan kata (symbol verbal) yang makna atau maksudnya benar-benar dipahami anak didik (tidak verbalistik).

\section{Fungsi Manipulatifa}

Fungsi manipulative ini didasarkan pada ciri-ciri (karakteristik) umum yang dimilikinya sebagaimana diesbut di atas. Berdasarkan karakteristik umum ini, media memiliki dua kemampuan, yakni mengatasi batas-batas ruang waktu dan mengatasi keterbatasan inderawi.

\section{Hakekat Powerpoint}

Media Microsoft Powerpoint adalah suatu media audio visual yang berbentuk 
Penerapan Media Powerpoint Untuk Meningkatkan Aktivitas Dan Hasil Belajar Pengetahuan Dasar Teknik Bangunan Pada Siswa Kelas X Program Keahlian Gambar Bangunan SMK Negeri 1 Merdeka Berastagi Tahun Ajaran 2012/2013

aplikasi dari program komputer, yang digunakan sebagai alat bantu untuk memaparkan atau mempresentasikan sebuah materi tertentu. Aplikasi ini biasa dipakai oleh dunia bisnis, akademis, pelatihan dan lainnya. Microsoft Power Point merupakan sebuah software yang dibuat dan dikembangkan oleh perusahaan Microsoft, dan merupakan salah satu program berbasis multi media.

Didalam komputer, biasanya program ini sudah dikelompokkan dalam program Microsoft Office.Program ini dirancang khusus untuk menyampaikan presentasi, baikyang diselenggarakan oleh perusahaan, pemerintahan, pendidikan, maupun perorangan, dengan berbagai fitur menu yang mampu menjadikannya sebagai media komunikasi yang menarik.Beberapa hal yang menjadikan media ini menarik untuk digunakan sebagai alat presentasi adalah berbagai kemampuan pengolahan teks, warna,dan gambar, serta animasi-animasi yang bisa diolah sendiri sesuai kreatifitas penggunanya.

Kelebihan Powerpoint memiliki kelebihan dibandingkan dengan softwere sejenis lainnya yang menyebabkannya menjadi softwere presentasi paling terkenal didunia. Fiturnya antara lain : 1). Antara mukanya sangat intuitif 2). Mudah dioperasikan 3). Tidak memboroskan resource computer 4). Dipaketkan bersamaan dengan Microsoft Office 5). Didukung oleh Microsoft Corporation 6). Tersedia di Windows dan Macintosh, Uraian di atas merupakan kelebihan media Microsoft Powerpointdari segi Fiturnya saja.

Jika media Microsoft Powerpoint digunakan dalam proses belajar mengajar, media Microsoft Powerpoint dapat digunakan untuk menyampaiakan materi dengan penyampaian yang menarik. Secarateoritis, sejauh ini media Microsoft Powerpoint di dalam proses belajar mengajar memiliki beberapa kelebihan diantaranya :1). Penyajiannya menarik karena ada permainan warna, huruf dan animasi,baik animasi teks maupun animasi gambar atau foto.2). Lebih merangsang anak untuk mengetahui lebih jauh informasi tentang bahan ajar yang tersaji.3). Pesan informasi secara visual mudah dipahami peserta didik.4). Tenaga pendidik tidak perlu banyak menerangkan bahan ajar yang sedang disajikan.5). Dapat diperbanyak sesuai kebutuhan, dan dapat dipakai secara berulang-ulang6). Dapat disimpan dalam bentuk data optik atau magnetik. (CD / Disket /Flashdisk), sehingga paraktis untuk di bawa ke mana-mana.Namun demikian, media hanyalah sebagai alat bantu, disisi lainmedia selain mempunyai kelebihan pastinya juga mempunyai kekurangan.Begitu juga media Microsoft Powerpoint selain mempunyai kelebihan juga mempunyai kekurangan-kekurangan. Adapun kekurangankekurangandari media Microsoft Powerpoint diantaranya adalah:1). Harus ada persiapan yang cukup menyita waktu dan tenaga. 2). Jika yang digunakan untuk presentasi di kelas adalah PC, maka parapendidik harus direpotkan oleh pengangkutan dan penyimpanan PCtersebut. 3). Jika layar monitor yang digunakan terlalu kecil (14"-15"), makakemungkinan besar siswa yang duduk jauh dari monitor kesulitanmelihat sajian bahan ajar yang ditayangkan di PC tersebut. 4). Para pendidik harus memiliki cukup kemampuan untukmengoperasikan program ini, agar jalannya presentasi tidak banyak hambatan. Herianto (sistem informasi UKDW-Tutor microsoft powerpoint) menjelaskan bahwa pada hakekatnya powerpoint memiliki kelebihan dan kekurangan. Kelebihan dan kekurangan powerpoint sebagai berikut:

a. Kelebihan Power Point 
1) Menyediakan jenis template yang konsisten dan kemas.

2) Menyediakan operasi yang mudah untuk mengorganisasikan kesemua elemen reka bentuk, latar, warna, corak serta aturan perisian.

3) Menambah gambar atau objek ke dalam slaid yang disediakan bila-bila sahaja.

4) Dapat melahirkan animasi slaid.

b. Kelemahan Power Point

1) Perlu mempertimbangkan keperluan penggunaan kesan animasi dalam menyediakan slaid supaya pelajar tidak hanya tertarik kepada animasi slaid.

2) Memerlukan kemahiran dan pengetahuan dari segi peruntukan wang, pengawalan masa pembelajaran sebenar, tempat yang sesuai serta kemudahan teknologi komputer yang lengkap.

3) Perlu mempertimbangkan kesan penglihatan pelajar terhadap slaid yang disediakan.

\section{B. Kerangka Konseptual}

Penggunaan media sebagai sarana pendukung dalam penyampaian informasi dalam proses pembelajaran merupakan salah satu faktor penting untuk meningkatkan hasil belarjar siswa. Salah satu jenis media pengajaran yang dapat digunakan dalam proses belajar mengajar adalah media Microsoft powerpoint. Microsoft powerpoint adalah suatu software yang akan membantu sebuah bahasan dalam pembelajaran menjadi lebih menarik dan jelas. Adapun fungsi media powerpoint dalam pembelajaran antara lain: (1)memperjelas penyajian pesan agar tidak terlalu verbelitas; (2) efektif dan bervariasi sehingga dapat mengatasi sikap pasif anak didik; (3) memberikan perangsang yang sama mempersamakan pengalaman, menimbulkan persepsi yang sama; (4) siswa cenderung lebih tertarik; (5) timbulnya rasa semangat dalam diri siswa. Penggunaan media Microsoft Power Point dalam mata pelajaran PDTB dapat memberikan.

Dengan penerapan powerpoint sebagai media belajar melalui penelitian tindakan kelas diharapkan akan dapat meningkatkan hasil belajar dalam pembelajaran PDTB.

\begin{tabular}{|c|c|c|}
\hline 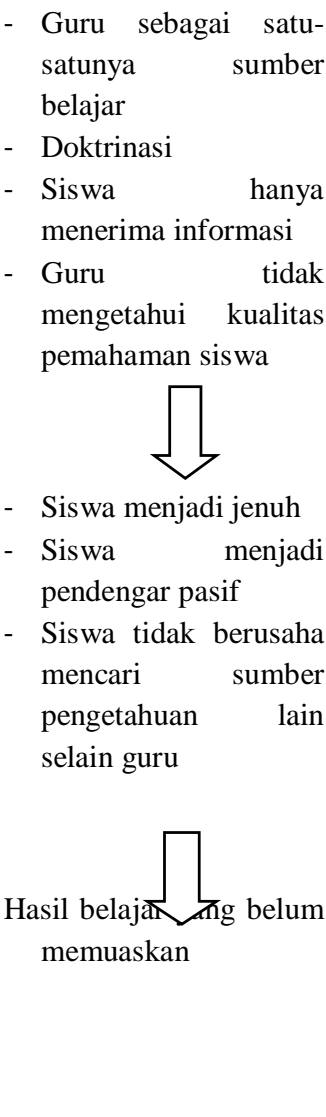 & $\begin{array}{c}\text { Pener } \\
\text { apan } \\
\text { media } \\
\text { Powe } \\
\text { rpoint } \\
\text { denga } \\
n \\
\text { Peneli } \\
\text { tian } \\
\text { Tinda } \\
\text { kan }\end{array}$ & $\begin{array}{l}\text { - Guru sebagai } \\
\text { fasilitator } \\
\text { siswa untuk } \\
\text { mencari } \\
\text { sumber } \\
\text { belajar } \\
\text { - } \text { Interaktif } \\
\text { - Siswa } \\
\text { mengelola } \\
\text { informasi } \\
\text { - Guru } \\
\text { mengetahui } \\
\text { kualitas } \\
\text { pemahaman } \\
\text { siswa }\end{array}$ \\
\hline
\end{tabular}

\section{Bagan Kerangka Konseptual}

\section{Hipotesis Penelitian}

Wardani dalam harahap (2009) mengatakan bahwa hipotesis tindakan adalah suatu pikiran tentang tindakan yang diduga dapat mengatasi permasalahan. Tindakan dilakukan dengan cara mengintervensi kegiatan agar dapat memperbaiki proses 
Penerapan Media Powerpoint Untuk Meningkatkan Aktivitas Dan Hasil Belajar Pengetahuan Dasar Teknik Bangunan Pada Siswa Kelas X Program Keahlian Gambar Bangunan SMK Negeri 1 Merdeka Berastagi Tahun Ajaran 2012/2013

pembelajaran. Artinya mengubah kegiatan atau tindakan yang bisa dilakukan dengan tindakan yang diduga sapat memperbaiki keadaan.

Penelitian ini direncanakan terbagi kedalam dua siklus, setiap siklus dilaksanakan mengikuti prosedur perencanaan (planning), tindakan (acting), pengamatan (observing), dan refleksi (reflecting).

Dengan melihat indikator keberhasilan maka dapat diduga bahwa :

1. Dengan diterapkannya powerpoint sebagai media belajar dapat meningkatkan hasil belajar mata pelajaran PDTB siswa kelas $\mathrm{X}$ program keahlian Teknik gambar banguna SMK Negeri 1 Merdeka.

2. Penggunaan media belajar powerpoint dapat meningkatkan aktivitas siswa dalam pembelajaran.

\section{METODOLOGI PENELITIAN}

\section{A. Tempat dan Waktu Penelitian}

Penelitian ini dilaksanakan di SMK N 1 Merdeka Tahun Pembelajaran 2012/2013 pada keahlian teknik gambar bangunan, yang beralamat di Jln. Pendidikan Berastagi Kabupaten Karo. Penelitian ini dilaksanakan pada bulan Desember 2012.

\section{B. Subjek Penelitian}

Subjek dalam Penelitian ini adalah siswa kelas X Program Keahlian Teknik Gambar Bangunan SMK N 1 Merdeka Tahun ajaran 2012/2013 dengan jumlah siswa 30 orang.

\section{Metode Penelitian}

Penelitian Tindakan Kelas atau PTK (Classroom Action Research) memiliki peranan yang sangat penting dan strategis untuk meningkatkan mutu pembelajaran apabila diplementasikan dengan baik dan benar. Diplementasikan dengan baik, artinya pihak yang terlibat dalam PTK (guru) mencoba dengan sadar mengembangkan kemampuan dalam mendeteksi dan memecahkan masalah-masalah yang terjadi dalam pembelajaran dikelas melalui tindakan bermakna yang diperhitungkan dapat memecahkan masalah atau memperbaiki situasi dan kemudian secara cermat mengamati pelaksanaaannya untuk mengukur tingkat keberhasilannya. Diplementasikan dengan benar, artinya sesuai dengan kaidahkaidah PTK. Upaya PTK diharapkan dapat menciptakan sebuah budaya belajar (Learning Culture) dikalangan para guru. Kunandar,(2008) menyatakan PTK menawarkan peluang sebagai strategi pengembangan kenerja sebab pendekatan penelitian ini menempatkan guru sebagai peneliti, agen perubahan yang pola kerjanya bersifat kolaboratif.

Menurut Arikunto (2008) Penelitian Tindakan Kelas merupakan suatu pencermatan terhadap kegiatan belajar berupa sebuah tindakan yang sengaja dimunculkan dan terjadi dalam sebuah kelas secara bersama. Tindakan tersebut diberikan oleh guru atau dengan arahan guru yang dilakukan oleh siswa.

\section{Rancangan Penelitian}

Penelitian tindakan kelas ini dilaksanakan melalui dua siklus dan masingmasing silklus terdiri dari empat tahapan untuk melihat peningkatan hasil belajar melalui media pembelajaran powerpoint.

Penelitian tindakan kelas memiliki beberapa model, dalam hal ini peneliti menggunakan model yang digunakan oleh Arikunto (2008).

\section{E. Kegiatan Penelitian}

Pelaksanaan penelitian tindakan ini dilaksanakan dalam dua siklus dan tiap siklus diselesaikan sampai standar kompetensi 
Penerapan Media Powerpoint Untuk Meningkatkan Aktivitas Dan Hasil Belajar Pengetahuan Dasar Teknik Bangunan Pada Siswa Kelas X Program Keahlian Gambar Bangunan SMK Negeri 1 Merdeka Berastagi Tahun Ajaran 2012/2013

dalam pembelajaran telah tercapai Arikunto,( 2008). Adapun pelasaksanaan tindakan yang dilakukan selama dua siklus
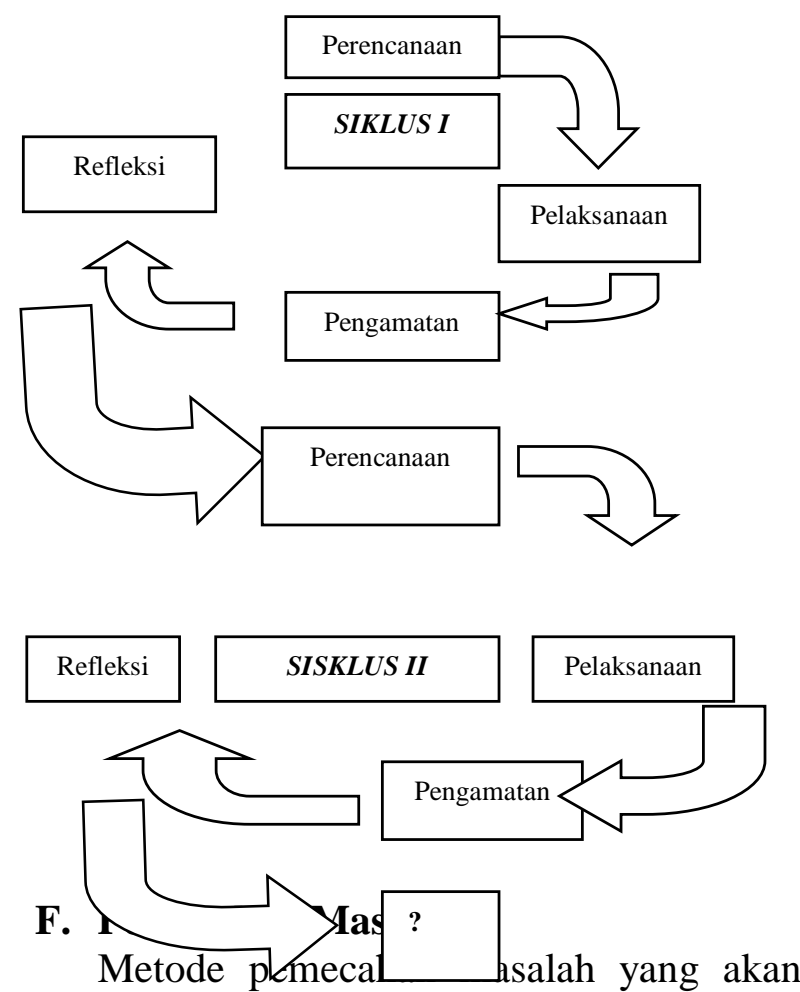
digunakan yaitu penelitian tindakan kelas dengan menerapkan media powerpoint. Penerapan strategi pembelajaran ini diharapkan dapat meningkatkan hasil belajar siswa pada mata pelajaran Pengetahuan Dasar Teknik Bangunan.

\section{G. Teknik dan Alat Pengumpulan Data \\ 1. Tes}

Pada paradigma kuantitatif digunakan untuk data hasil belajar siswa sesuai dengan kompetensi yang telah ditetapkan dalam bentuk tes kognitif. Tes kognitif hasil belajar siswa adalah seperangkat tes kognitif dalam bentuk objektif tes dengan pilihan berganda yang digunakan untuk memperoleh data hasil belajar pada kompetensi yang ditentukan dalam kisi kisi instrumen.

\section{Observasi}

Observasi digunakan untuk mengumpulkan data tentang aktivitas belajar siswa dalam proses belajar mengajar dan menerapan media powerpoint. Adapun format observasi yang dirancang peneliti.

\section{H. Uji Coba Instrumen Penelitian}

Sebelum peneliti melaksanakan penelitian maka terlebih dahulu dilakukan uji coba instrumen penelitian yang dilakukan di SMK N 1 Lubuk Pakam dengan jumlah soal 45 soal tes pilihan berganda dengan pengelompokan 20 soal untuk siklus I dan 25 soal untuk siklus II. Uji coba penelitian ini bertujuan untuk mendapatkan alat ukur yang benar-benar dapat menjaring data yang akurat agar kesimpulan yang diambil sesuai dengan kenyataan. Adapun yang diuji dalam uji coba instrumen penelitian adalah sebagai berikut:

1. Validitas Tes

2. Realibilitas

3. Uji Daya Pembeda

4. Uji Tingkat Kesukaran

\section{HASIL PENELITIAN DAN PEMBAHASAN}

\section{A. Hasil Penelitian}

Penelitian ini dilaksanakan di SMK N 1 Merdeka Berastagi dengan menerapkan media Powerpoint untuk meningkatkan aktivitas dan hasil belajar Pengetahuan Dasar Teknik Bangunan siswa kelas X Program Keahlian Teknik Gambar Bangunan di SMK N 1 Merdeka Berastagi Tahun Ajaran 2012/2013. Penelitian ini merupakan Penelitian Tindakan Kelas (Classroom Action Research). Penelitian ini dilaksanakan dalam dua siklus dimana dalam siklus pertama diselesaikan dengan 2 kali pertemuan dan siklus kedua diselesaikan dengan 2 kali pertemuan, dimana dalam satu siklus terdiri 
Penerapan Media Powerpoint Untuk Meningkatkan Aktivitas Dan Hasil Belajar Pengetahuan Dasar Teknik Bangunan Pada Siswa Kelas X Program Keahlian Gambar Bangunan SMK Negeri 1 Merdeka Berastagi Tahun Ajaran 2012/2013

dari empat tahapan, yaitu: 1). Perencanaan, 2). Pelaksanaan, 3). Pengamatan dan 4). Refleksi.

Tahap perencanaan merupakan kegiatan yang sangat penting untuk mendukung proses tindakan yang akan dilakukan dengan mempersiapkan perangkat-perangkat pembelajaran sebagai instrument dalam proses pembelajaran.

Setelah itu guru akan menerapkan media powerpoint serta memberikan soal berbentuk pilihan berganda pada akhir tindakan. Selanjutnya dilakukan pengamatan (observation) dan evaluasi untuk mengetahui peningkatan hasil belajar siswa setelah pembelajaran. Dari hasil evaluasi tersebut maka ditemukan masalah-masalah baru (reflection). Jika hasil belajar siswa belum mencapai Kriteria Ketuntasan Minimum yaitu sebesar 70 dan aktivitas siswa belum meningkat $50 \%$ dari jumlah siswa maka siklus I dikatakan belum berhasil, sehingga perlu dilanjutkan siklus II dengan memfokuskan pembelajaran terhadap kesulitan-kesulitan belajar yang dihadapi siswa pada siklus I.

Penelitian Tindakan Kelas dalam pelaksanaannya memiliki siklus untuk melakukan pemecahan menuju praktik pembelajaran yang lebih baik. Penelitian ini akan dilakukan dalam dua siklus dimana siklus I diselesaikan dalam 1 kali pertemuan, dan siklus II diselesaikan dalam 1 kali pertemuan yang dideskripsikan sebagai berikut:

\section{Siklus}

\subsection{Tahap Perencanaan}

Sesuai dengan ciri khas Penelitian Tindakan Kelas (PTK) yaitu penelitian yang berawal dari permasalahan yang timbul dalam proses pembelajaran yang dihadapai oleh guru. Maka peneliti melaksanakan tahap perencanaan (Planning) yaitu melakukan konsultasi dengan PKS I untuk menentukan silabus, kurikulum dan RPP dan bekerjasama dengan guru bidang studi dalam menentukan materi pokok pembelajaran serta untuk mengetahui keadaan siswa di sekolah. Adapun materi pokok untuk siklus I adalah Tegangan. Peneliti mempersiapkan format observasi untuk melihat aktivitas dan hasil belajar siswa. Peneliti akan melakukan kolaborasi dengan guru bidang studi untuk melaksanakan tindakan yang telah direncanakan sebelumnya.

\subsection{Tahap Tindakan}

Dalam tahap ini, pembelajaran dimulai dengan memperkenalkan materi pelajaran sesuai dengan Rencana Perencanaan Pembelajaran (RPP) yang telah disusun sebelumnya dengan melakukan tindakan penerapan media Powerpoint. Dalam tahap tindakan pembelajaran ini guru menjelaskan serta memberi penugasan siswa dan siswa mempertanggungjawabkan hasil pekerjaannya. Setelah tindakan selesai, dilakukan evaluasi belajar dengan memberikan tes pilihan berganda. Pada tahap ini peneliti langsung mengawasi dan membimbing siswa serta memberikan penjelasan yang perlu jika terdapat kesulitan-kesulitan yang dialami siswa dalam proses pembelajaran.

\subsection{Tahap Pengamatan}

Pada saat siswa melakukan pembelajaran di kelas peneliti telah mengambil posisi duduk dibelakang siswa untuk melakukan observasi aktivitas siswa. Setiap kelompok akan dilakukan pengamatan terhadap aktivitas siswa selama proses tindakan berlangsung. Dari hasil pengamatan tersebut akan diperoleh aktivitas siswa untuk diolah setelah proses 
Penerapan Media Powerpoint Untuk Meningkatkan Aktivitas Dan Hasil Belajar Pengetahuan Dasar Teknik Bangunan Pada Siswa Kelas X Program Keahlian Gambar Bangunan SMK Negeri 1 Merdeka Berastagi Tahun Ajaran 2012/2013

pembelajaran selesai. Berikut ini akan dijelaskan aktivitas siswa selama proses pembelajaran berlangsung.

\subsection{Tahap Refleksi}

Setelah melakukan pelaksanaan tindakan selesai maka peneliti melihat hasil observasi (pengamatan) yang meliputi:

1. Pelaksanaan pembelajaran dengan powerpoint

Pada proses pembelajaran berlangsung siswa tidak atau kurang memperhatikan guru kebanyakan siswa sibuk dengan kegiatan masing-masing.

2. Hasil belajar siswa

Hasil belajar siswa pada siklus 1 sebelum menggunakan powerpoint dikatakan belum berhasil di mana katagori cukup dan baikbelum mencapai 50\% sehingga perlu di lakukan siklus 2 .

3. Aktivitas belajar siswa

Refleksi terhadap aktivitas belajar ada beberapa aspek yang di lakukan meliputi antusias, bertanya, mengeluarkan pendapat, memberikan jawaban, mengerjakan tugas.

a. Antusias dalam mengikuti Kegiatan Belajar Mengajar

Dari hasil observasi aktivitas belajar siswa siklus I diketahui antusias dalam mengikuti KBM berada pada kriteria nilai dilakukan dengan baik yaitu 2,76 dengan presentase nilai $69 \%$, maka katagori nilai dikatakan tidak aktif.

b. Bertanya

Dari hasil observasi aktivitas belajar siswa siklus I diketahui mengajukan pertanyaan berada pada kreteria nilai dilakukan dengan cukup baik yaitu 1,93 dengan presentase nilai 48,25\%, maka katagori nilai dikatakan tidak aktif.

c. Mengeluarkan Pendapat
Dari hasil observasi aktivitas belajar siswa siklus I diketahui mengeluarkan pendapat berada pada kreteria nilai dilakukan dengan cukup baik yaitu 1,86 dengan presentase nilai 46,5\%, maka katagori nilai dikatakan tidak aktif.

\section{d. Memberikan Jawaban}

Dari hasil observasi aktivitas belajar siswa siklus I diketahui memberikan jawaban berada pada kreteria nilai dilakukan dengan baik yaitu 2,36 dengan presentase nilai 59\%, maka katagori nilai dikatakan tidak aktif.

e. Mengerjakan Tugas

Dari hasil observasi aktivitas belajar siswa siklus 1 diketahui mengerjakan tugas berada pada kreteria nilai hasil yaitu 2,66 dengan presentase nilai $66,5 \%$, maka katagori nilai dikatakan tidak aktif.

\section{SIMPULAN, IMPLIKASI DAN SARAN}

\section{A. Simpulan}

Dari hasil analisis data dan pembahasan maka dapat diambil kesimpulan, yaitu:

1. Hasil aktivitas siswa mengalami peningkatan dari siklus I ke siklus II, dimana aktivitas siswa pada siklus I dengan kategori Tidak Baik (TB) adalah sebanyak 10 orang siswa $(33,33 \%$, ), kategori Kurang Baik (KB) adalah sebanyak 9 orang siswa (30\%), kategori Cukup Baik (CB) sebanyak 8 orang $(26.67 \%)$, kategori Baik sebanyak 3 orang (10\%).

Sedangkan pada siklus II aktivitas siswa mengalami peningkatan yaitu untuk kategori Tidak Baik (TB) dan Kurang Baik (KB) tidak ada (0\%), kategori Cukup Baik (CB) 5 orang siswa (16.67\%), kategori Baik (B) 21 orang siswa (70\%) dan kategori Sangat Baik (SB) 4 orang siswa $(13,33 \%)$.

2. Rata-rata hasil belajar siswa setelah dilakukan penerapan media powerpoint adalah mengalami peningkatan, dimana 
Penerapan Media Powerpoint Untuk Meningkatkan Aktivitas Dan Hasil Belajar Pengetahuan Dasar Teknik Bangunan Pada Siswa Kelas X Program Keahlian Gambar Bangunan SMK Negeri 1 Merdeka Berastagi Tahun Ajaran 2012/2013

dari siklus I nilai rata-rata hasil belajar siswa adalah 62,17 meningkat menjadi 81,50 dengan rata-rata peningkatan penguasaan materi pada siklus I dan siklus II sebesar $19.33 \%$.

Dari hasil peningkatan hasil belajar tersebut berarti bahwa penerapan media powerpoint pada mata diklat pengetahuan dasar teknik bangunan mengalami peningkatan. Oleh karena itu, penerapan media powerpoint dapat meningkatkan hasil belajar pengetahuan dasar teknik bangunan siswa kelas $\mathrm{X}$ Program Keahlian Teknik Gambar Bangunan di SMK Negeri 1 Merdeka Berastagi Tahun Ajaran 2012/2013.

3. Nilai hasil belajar pengetahuan dasar teknik bangunan dan nilai aktivitas belajar siswa pada mata diklat pengetahuan dasar teknik bangunan merupakan nilai yang terpisah dan berbeda. Sehingga terdapat siswa yang memiliki nilai aktivitas belajar tinggi tetapi tidak terlalu tinggi dalam hasil belajar pengetahuan dasar teknik bangunan dan begitu juga sebaliknya.

\section{B. Implikasi}

Berdasarkan hasil penelitian dan kesimpulan penelitian, maka implikasi dalam penelitian ini adalah perlu adanya upaya dari pihak sekolah dalam memberikan pengarahan-pengarahan tentang penggunaan media powerpoint dalam pembelajaran karena dapat meningkatkan hasil belajar dan aktivitas siswa dalam belajar.

Adanya peningkatan hasil belajar perlu menjadi pertimbangan bagi guru untuk mengunakan media powerpoint dalam pembelajaran. Upaya guru dalam menerapkan penggunaan media powerpoint dalam pembelajaran dapat berupa musyawarah bersama setiap guru tentang proses pembelajaran tentang menggunakan media powerpoint. Pembelajaran dengan mengunakan media powerpoint dapat meningkatkan aktivitas siswa dalam belajar, sehingga hendaknya para guru memberikan pengarahan kepada sisiwa bahwa belajar dilakukan sendiri oleh siswa, guru sebagai fasilataor dalam proses pembelajaran.

\section{Saran}

Berdasarkan kesimpuan di atas, saran yang dapat diberikan untuk pelaksanaan penerapan media power point adalah :

1. Diharapkan kepada guru mata diklat pengetahuan dasar teknik bangunan agar dapat menerapkan media powerpoint untuk meningkatkan aktivitas dan hasil belajar siswa.

2. Diharapkan kepada peneliti selanjutnya agar dalam penerapan media powerpoint ini menggunakan standar kompetensi yang berbeda, media belajar yang lengkap sehingga aktivitas dan hasil belajar siswa mengalami peningkatan.

\section{DAFTAR PUSTAKA}

Arsyad, A.(2000). Media Pengajaran, Penerbit Raja Grafindo Parsada, Jakarta.

Effendi, E \& Zhuang, Hartono. (2005). ELearning-Konsep dan Aplikasi. : CV. Andi OFFset. Yogyakarta

Hamalik, o. (1993). Metode belajar dan kesulitan belajar, Tarsito, Bandung.

Harahap, Zahrani. (2009). Peningkatan Hasil Belajar Mata Diklat Fisika Melalui Penerapan Peta Konsep Di Keles X Program Keahlian Teknik Gambar Bangunan SMK Negeri 1 Stabat Tahun Pelajaran 2008/2009.(Skripsi).FT. UNIMED, Medan

Hidayat, J (2008). Penggunaan Microsoft Powerpoint Sebagai Media TIK. 
Penerapan Media Powerpoint Untuk Meningkatkan Aktivitas Dan Hasil Belajar Pengetahuan Dasar Teknik Bangunan Pada Siswa Kelas X Program Keahlian Gambar Bangunan SMK Negeri 1 Merdeka Berastagi Tahun Ajaran 2012/2013

Diakses 28 Juni 2012, Pada http://media.diknas.go.id /media/document/5540.pdi

Iskandar.(2009). Penelitian Tindakan Kelas. Gedung Parsada (GP) Press, Ciputat: Jakarta

Sudjana, N.(1998). Dasar-Dasar Proses Belajar Mengajar, Tarsito, bandung. Sukardi.(2008).Metodologi Penelitian Tindakan. Bumi Aksara. Jakarta 